Volume 9, No.5, September - October 2020

International Journal of Advanced Trends in Computer Science and Engineering

Available Online at http://www.warse.org/IJATCSE/static/pdf/file/ijatcse226952020.pdf

https://doi.org/10.30534/ijatcse/2020/226952020

\title{
A Blockchain System For Digital Payment Transaction
}

\author{
Jennifer Alexandra ${ }^{1}$, Muhamad Fadhly ${ }^{2}$, Gunawan Wang ${ }^{3}$, Sfenrianto $^{4}$ \\ 1,2,3,4 Information Systems Management Department, BINUS Graduate Program - Master of Information System \\ Management, Bina Nusantara University, Jakarta, Indonesia 11480, e-mail: ${ }^{1}$ Jennifer.alexandra001@ binus.ac.id, \\ ${ }^{2}$ muhamad.fadhly@binus.ac.id, ${ }^{3}$ gwang@binus.edu, ${ }^{4}$ sfenrianto@binus.edu
}

\begin{abstract}
In this modern times, there are various options for conducting financial transaction or payment. This is related to the rapid development of technology that can make payment transaction more easily and practically. The entry of technology can not be denied to affect all various aspects of human life, including in the case of buying and selling or the use of cash to the bill payment process. If we can see, In Indonesia many digital based financial services are present, such as e-wallet like Sakuku, LinkAja, Go-Pay, OVO, Jenius, Dana, etc. With this service, people can make payment transaction for various purposes with the existing balance in e-wallet. The use of e-wallet is considered more convenient and profitable. It is considered to be more convenient because it is sufficient to carry out all transaction only from mobile phone. It's profitable because usually you will be offered lots of discounts and cashback from merchants who work with e-wallet providers. According to survey conducted by Databooks.co.id, this is the most 10 frequently used e-wallet in Indonesia 2020.
\end{abstract}

Key words :Digital Payment, E-Wallet, Billing, Blockchain

\section{INTRODUCTION}

When the development of the digital 4.0 era has explored all fields, both in the fields of education, technology, financial, and other fields. All fields have been supported bytechnology[1]. In this modern times, there are various options for conducting financial transaction or payment. This is related to the rapid development of technology that can make payment transaction more easily and practically. The entry of technology can not be denied to affect all various aspects of human life, including in the case of buying and selling or the use of cash to the bill payment process. If we can see, In Indonesia many digital based financial services are present, such ase-wallet like Sakuku, LinkAja, Go-Pay, OVO, Jenius, Dana, etc. With this service, people can make payment transaction for various purposes with the existing balance in e-wallet. The use of e-wallet is considered more convenient and profitable. It is considered to be more convenient because it is sufficient to carry out all transaction only from mobilephone. It's profitable because usually you will be offered lots of discounts and cashback from merchants who work with e-wallet providers. According to survey conducted by Databooks.co.id, this is the most 10 frequently used e-wallet in Indonesia 2020.

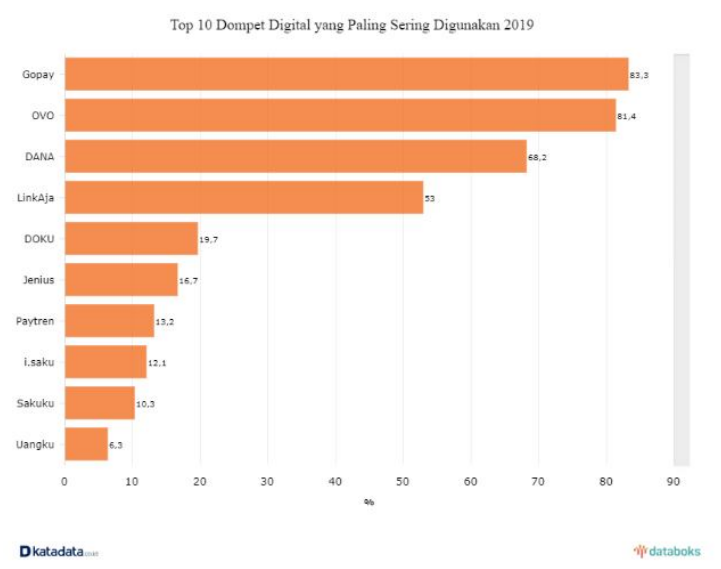

Figure 1:10 frequently used e-wallet in Indonesia 2020 [2].

Currently Indonesia has many kinds of e-wallet applications, that is 38 e-wallet which have been registered with Bank Indonesia. According to data from Social \& Statistics, in 2018 a total of 22,338 million US dollars of transaction made by Fintech which included the use of e-wallet[3].This is the reason, the use of E-wallet will continue to increase from year to year. In Rapyd's research, the Asia Pacific eCommerce and Payment Guide 2020, conducted in April 2020 also showed that online transaction using e-wallets have surpassed the use of bank debit card and ATMs in the past month[4].

The process of payment transaction using e-wallet application is considered more practical, the customer will top up the balance into the e-wallet, then the customer can simply choose the payment menu such as payment of electricity bills to PLN. Automatically, the balance will be taken from the customer's e-wallet and sent directly to PLN. After the process is complete, both parties (customer and PLN) will receive what they expect. The role of the e-wallet application here is being a third party 
or intermediary between the customer and biller. But even though online bill payment using e-wallet are considered more easier and more convenient, sometimes it can be a problem due to an error from the third party so the payment made by customernot directly verified and this situation can make the customer get fines because they are considered late making payment, while in fact the problem is not from the customer[5].All of this can happen because of there is norecordingof bill payment transaction.

With the Blockchain technology where every transaction that occurs will be recorded and secured in many databases that are widely distributed on the computer, then all transaction no longer need to depend on one server, because the transaction will be replicated to the entire network. Because the nature of the network is peer to peer, blockchain user can also avoid various frauds that can occur. Based on the reasons above, this paper will be focusing on the discussion of Blockchain for digital payment transaction by designing application designs with a decentralized peer-to-peer concept that can speed up the payment process and be more transparent so there are no more problems such as customer payment that experience delays due to third party and it is expected that the recording of bill payment transaction will be better, all parties involved will systematically record all transaction, so that customer can monitor and will know the sequence of bill payment they pay until they are verified.

\section{Literature ReVIEW}

\subsection{Blockchain}

Blockchain is a concept where the data is not stored in a big storage system but they recorded and distributed through device or system that use blockchain-based system[6].Blockchain is an open and distributed ledger that can record all types of transaction that occur between two parties directly and more efficiently. The data in the Blockchain cannot be changed or is permanent, it can also be arranged to make transaction automatically[7].It can also be set to do transaction automatically. The utilization does not have to involve cryptocurrency. Blockchain technology has the potential to increase business opportunities and could have a significant impact on industries including financial systems due to its decentralized features that implemented on open protocol and standard[8]. Blockchain technology applies to all digital asset transaction exchanged online. Blockchain implementation in digital payment transaction will be useful. Blockchain makes the steps to achieve a trust-less environment that shows how paperless transaction with Blockchain technology usage can ensure better security and more transparent

\subsection{E-wallet}

E-wallet or electronic wallet is a digital payment instrument or digital payment instrument that uses electronic media in the form of server based[9]. In general, E-wallet is an application based on a server and in the process of using it requires a connection first with the publisher. Increasingly, digital wallets are being made not just for basic financial transaction but to also authenticate the holder's credentials. There are several E-wallet currently on the market, T-Cash Telkomsel, XL Cash, CIMB Niaga Mobile Accounts, BBM Money Permata Bank, DOKU, etc[10].

\subsection{Digital Payment}

Digital payment or better known asthe term electronic money, has two basic forms in the form of computer networks and digital systems[11]. Payment digital is a way of payment made through digital mode. In payment transaction, payers and recipients use digital mode to send and receive money. All digital payment transaction done online. Digital payment methods are more convenient and is more secure compared to making transaction involving cash withdrawal. Digital Payment system provides us a very easy medium of self payment on point of sale or Merchant Outlets[12].

Along with the development of technology, people began to change using digital payment and slowly left the cash payment system. This is because there are a lot of people already feel the benefits of using digital payment.

\subsection{Financial Technology}

FinTech refers to various financial technologies used to automate processes in the financial sector, from routine, manual tasks to nonroutine, cognitive decision making[13]. Various areas of finance are subject to disruption, such as payment systems, contract checking, trading, risk management, quantitative asset management, lending, mobile banking, customer retention, and investment banking.

Fintech is the implementation and utilization of technology for improving banking and financial servicesgenerally done by startup companies that utilize software, internet and communication technologies[14]. The basic forms of Fintech include Payment (digital wallets, Peer to Peer, payment), Investments (equity crowdfunding, Peer to Peer Lending), Financing (crowdfunding, micro-loans, credit facilities), Insurance (risk management), Cross process (big data) analysis, predicitive modeling), Infrastructure (security)

\section{RESEARCH METHODOLOGY}

\subsection{Analysis current situation}

The following is an illustration of bill payment transaction that have been carried out by customer who make bill payment through e-wallet. The role of e-wallet in this transaction is as an intermediary for payment to the biller, and then the e-wallet will report the payment that has been deposited to the biller for the customer as the reporting of payment charges, whereas on the other hand the biller also needs time to verify the customer for payment which has been deposited by the e-wallet. 


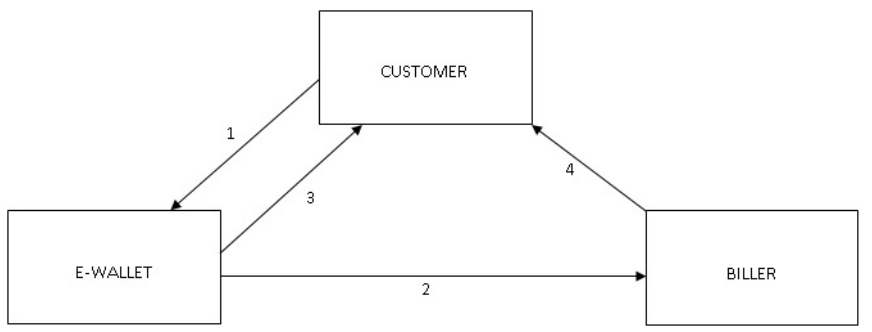

Figure 2:Usual digital payment transaction

1. Customer checking and pay billing to the biller via e-wallet application

2. E-wallet checking and pay billing by integration system

3. E-wallet returns paid report

4. Biller send verification payment to customer directly

From this channel, we can see there is the potential for a late payment verification. Because the biller provides the payment verification information does not coincide with the time of the payment process. And potential problems will also occur when the verification process is carried out by the biller to the customer, not through the e-wallet which is the intermediary for payment.

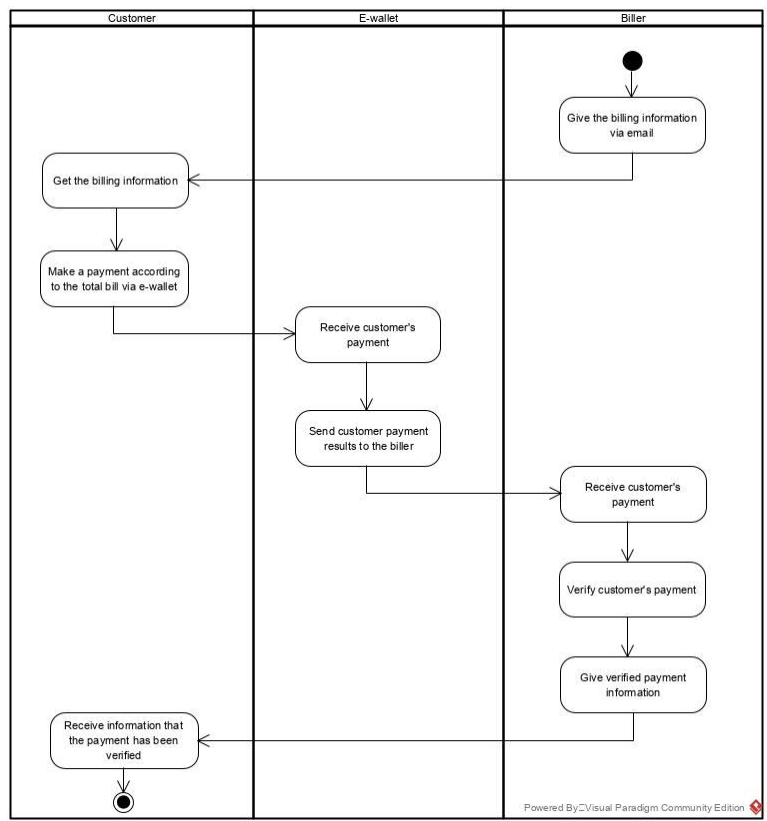

Figure 3: Example of usual payment transaction using e-wallet to biller

Here is an example study case of payment transaction using e-wallet to biller. The customer get an email regarding the payment bill information on 27 June 2020, then the customer make a payment two days after receiving the email, on 29 June 2020 using e-wallet. However, after the customer made a payment, the customer does not get any information related to their payment either from the e-wallet or from the Biller. After two days of making a payment on July 1, 2020,customer receive an email informing them that the customer's payment has been verified from Biller. Customer do not get any information related to their payment via e-wallets, which are the intermediaries between the customer and the biller.Here is an Use Case Diagram related to the case:

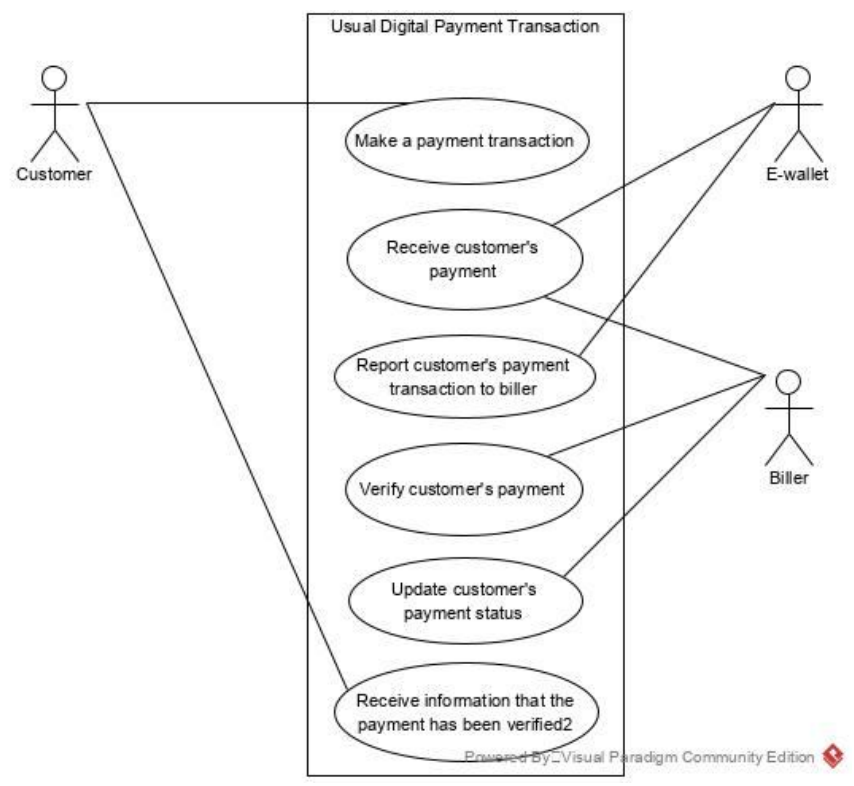

Figure 4: Use Case Diagram usual payment transaction using e-wallet to biller

\subsection{Blockchain for Digital Payment Transaction}

Utilizing blockchain methodology as an intermediary for recording transaction information, it is hoped that it will clarify the history of existing transaction records. Starting from the record of payment from cutomer to e-wallet, then depositing payment from cutomer to biller until verification of payment received by biller. All records will be recorded in a blockchain based system so that all parties involved can easily see clearly all transaction that appear on the flow of transaction that have occurred.

The following is an illustration of the proposed implementation of the blockchain in digital bill payment utilizing online transaction facilitated by e-wallet

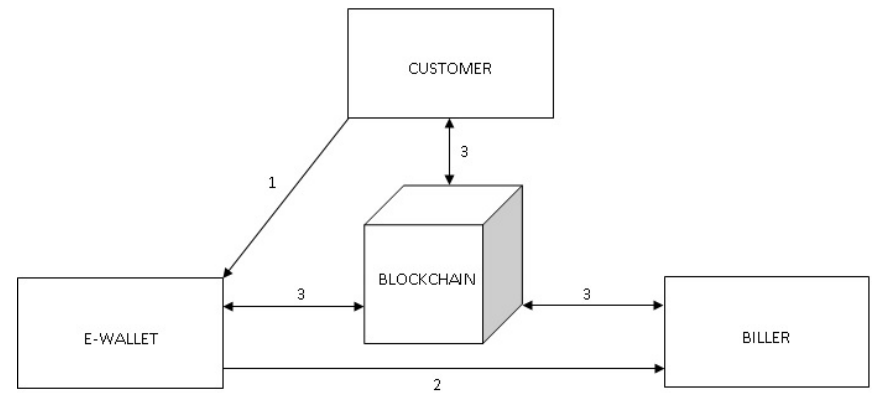

Figure5:Blockchain based digital payment transaction

1. Customer checking and pay billing to leasing via e-wallet application

2. E-wallet checking and pay billing by integration system

3. Post and get infomation transaction supported by blockchain technology

All elements of interest are required to record all actions into 
the blockchain in a system that is facilitated by e-wallet and biller in order to obtain a transaction record data that is structured and systematic and can also be monitored by all parties involved in a blockchain-based system cycle including customer who are very potentially as a party that has the potential to experience a loss in this bill payment transaction.

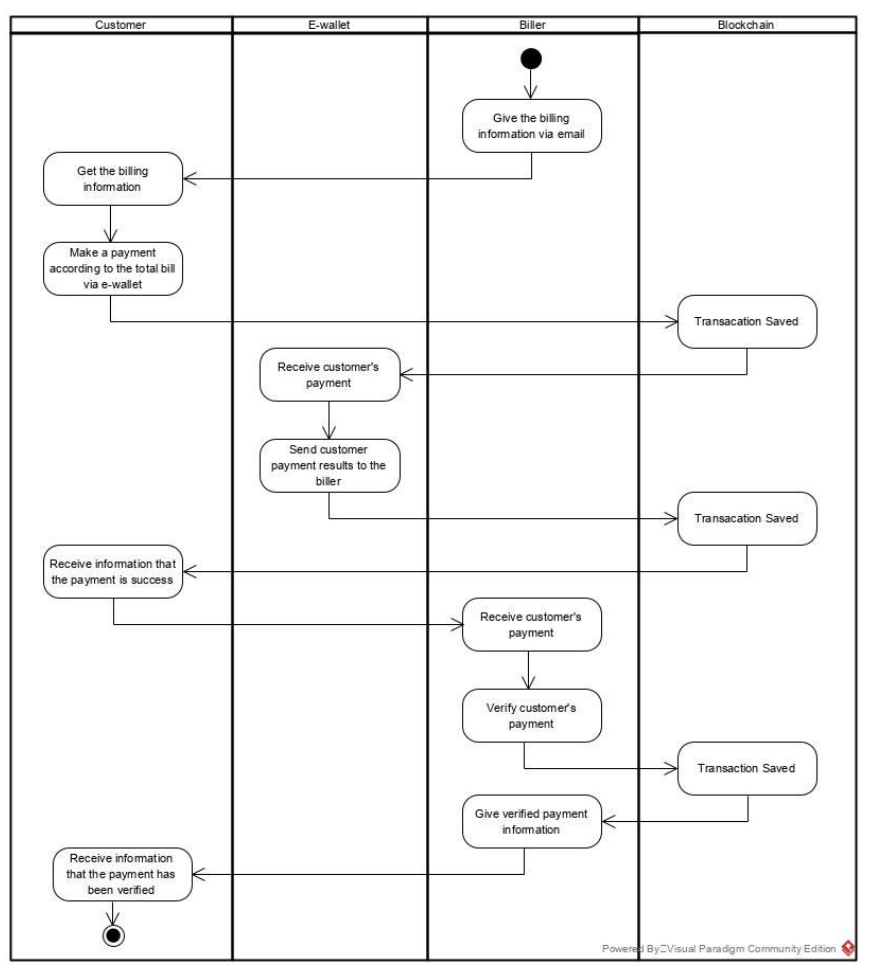

Figure6: Example of usual payment transaction using e-wallet to biller with Blockchain Technology

Here is an example study caseof payment transaction using e-wallet to billes who are already using the Blockchain Technology. The customer get an email regarding the payment bill information on 27 June 2020, then the customer make a payment two days after getting the email, on 29 June 2020 using e-wallet. After customer made a payment, the customer will immediately get information regarding the verification of the payment that has been made from e-wallet and also from the biller in the same day when customer made a payment. All transactions that occur will be stored and recorded clearly on the Blockchain and customer don't have to wait to get the confirmation of payment that have been made.Here is an Use Case Diagram related to the case:

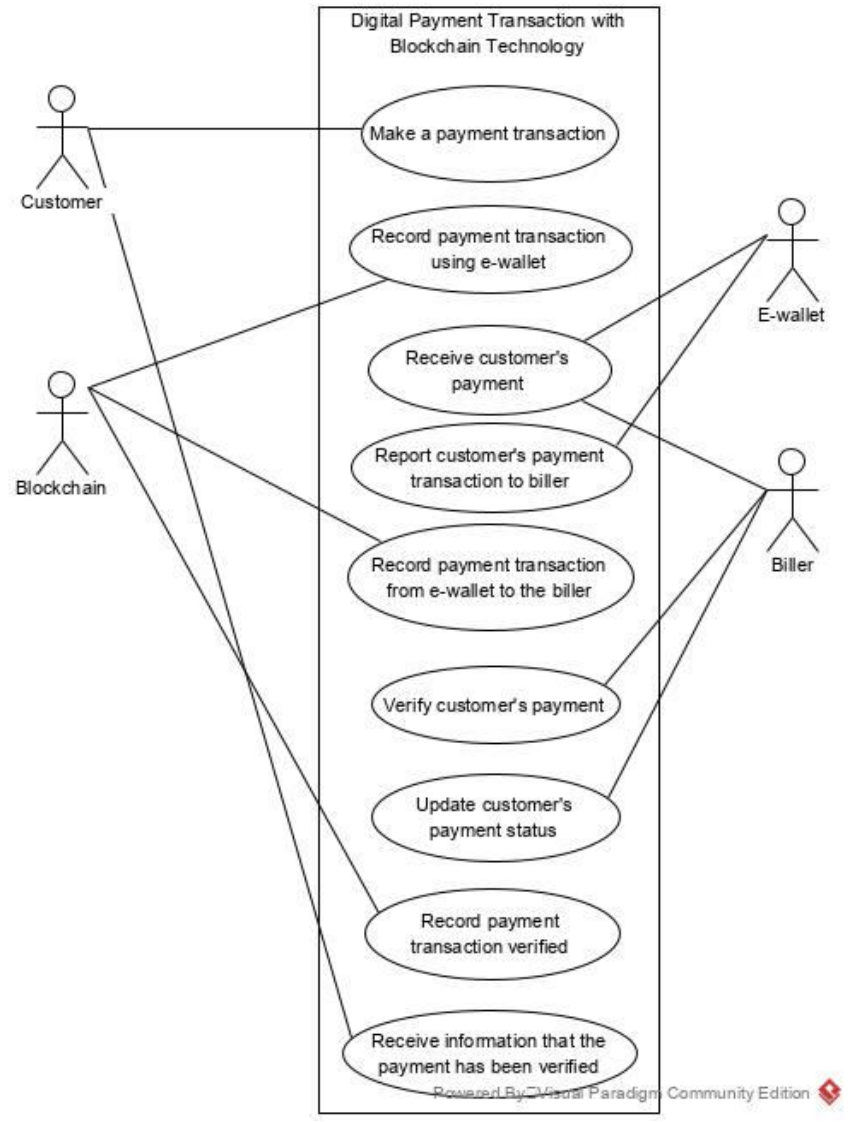

Figure7: Use Case Diagram usual payment transaction using e-wallet to biller with Blockchain Technology

\section{Conclusion}

The change of paradigm in the method of cash payment to digital payment methods is experiencing rapid expansion in Indonesia. Currently Indonesia already has many e-wallet applications that are frequently used by the society, such as Sakuku, LinkAja, Go-Pay, OVO, Jenius, Dana, etc. The use of e-wallet is considered to have many benefits, such as realizing cashless society, being able to track transaction, more safer, also more easier to make purchases or making payment.The blockchain effect on the digital payment transaction is also very significant.

As have been explained before that if a digital payment transaction is not using blockchain system, then where will be a possibility there is the potential for a late payment verification. Because the biller provides the payment verification information does not coincide with the time of the payment process. Therefore, we suggest using blockchain system to make every transaction that occurs will be recorded and make all data more integrated and all parties involved will get structured and systematic transaction log data and can also be monitored by all parties involved in the blockchain. 
Table 1 : comparison before and after using blockchain

\begin{tabular}{|c|c|}
\hline \multicolumn{2}{|c|}{ CUSTOMER } \\
\hline BEFORE BLOCKCHAIN & AFTER BLOCKCHAIN \\
\hline $\begin{array}{l}\text { Waiting for payment } \\
\text { reporting from e-wallet and } \\
\text { waiting for payment } \\
\text { verification from biller }\end{array}$ & $\begin{array}{l}\text { See the sequence of payment } \\
\text { transaction data on the } \\
\text { blockchain }\end{array}$ \\
\hline $\begin{array}{l}\text { There may be losses due to } \\
\text { delay in verification }\end{array}$ & $\begin{array}{l}\text { Blockchain data can be used } \\
\text { as a basis for arguing that } \\
\text { customers have already paid }\end{array}$ \\
\hline \multicolumn{2}{|c|}{ E-WALLET } \\
\hline BEFORE BLOCKCHAIN & AFTER BLOCKCHAIN \\
\hline $\begin{array}{l}\text { Record payment transaction } \\
\text { reports to and from customer } \\
\text { and reporting payment } \\
\text { deposits to the biller }\end{array}$ & $\begin{array}{l}\text { Record all transactions only } \\
\text { to the blockchain }\end{array}$ \\
\hline $\begin{array}{l}\text { E-wallets may be the part to } \\
\text { be blamed by the customer } \\
\text { due to late verification and } \\
\text { penalties }\end{array}$ & $\begin{array}{l}\text { By displaying data from the } \\
\text { blockchain, e-wallets can } \\
\text { avoid all accusations }\end{array}$ \\
\hline \multicolumn{2}{|c|}{ BILLER } \\
\hline BEFORE BLOCKCHAIN & AFTER BLOCKCHAIN \\
\hline $\begin{array}{l}\text { Verify payment from the } \\
\text { e-wallet and then report to } \\
\text { the customer }\end{array}$ & $\begin{array}{l}\text { Verifying billing payments to } \\
\text { blockchain }\end{array}$ \\
\hline $\begin{array}{l}\text { Billers only get payment data } \\
\text { from e-wallets }\end{array}$ & $\begin{array}{c}\text { The application of } \\
\text { blockchain, all data can be } \\
\text { presented clearly and in } \\
\text { detail also can avoid penalty } \\
\text { offenders }\end{array}$ \\
\hline
\end{tabular}

\section{REFERENCES}

[1] P. Sokibi, M. Asfi, Q. Aini, A. Khoirunisa, and U. Rahardja, "Ltai management based on blockchain technology to increase alexa rank," Int. J. Adv. Trends Comput. Sci. Eng., vol. 9, no. 4, pp. 4798-4802, 2020, doi: 10.30534/ijatcse/2020/88942020.

[2] D. H. Jayani, "Inilah Dompet Digital yang Paling Banyak Digunakan,” 2019. [Online]. Available: https://databoks.katadata.co.id/datapublish/2019/11/2 7/inilah-dompet-digital-yang-paling-banyak-digunak an.

[3] T. Apriyani, "E-wallet Alat Transaksi dan Pembayaran Zaman Now," Jakarta, 2019. [Online]. Available:

https:/www.suara.com/yoursay/2019/12/19/140313/ e-wallet-alat-transaksi-dan-pembayaran-zaman-now.

[4] M. Elena, "Alat Pembayaran E-wallet Geser Posisi Kartu Debit, Ovo di Peringkat Pertama," Jakarta, 2020. [Online]. Available: https://finansial.bisnis.com/read/20200612/90/12518 62/alat-pembayaran-e-wallet-geser-posisi-kartu-debit -ovo-di-peringkat-pertama.

[5] Krisnawati, "Kecewa dengan Pembayaran Tagihan Kartu Kredit di Bukalapak,” Jakarta, 2019. [Online]. Available:

https://mediakonsumen.com/2019/03/20/surat-pemba ca/kecewa-dengan-pembayaran-tagihan-kartu-kredit- di-bukalapak.

[6] A. P. Pertiwi, D. Puri, Y. A. Pratama, G. Wang, and Sfenrianto, "A blockchain-based smart contract system for digital video streaming application," Int. J. Adv. Trends Comput. Sci. Eng., vol. 9, no. 3, pp. 2708-2711, 2020, doi: 10.30534/ijatcse/2020/34932020.

[7] R. Ilham, S. Wisesa, W. Teguh, G. Wang, and Sfenrianto, "Smart contract formulation in general elections," Int. J. Emerg. Trends Eng. Res., vol. 8, no. 6, pp. 2233-2236, 2020, doi: 10.30534/ijeter/2020/03862020.

[8] N. Katuk, "The application of blockchain for halal product assurance: a systematic review of the current developments and future directions," Int. J. Adv. Trends Comput. Sci. Eng., vol. 8, no. 5, pp. 1893-1902, 2019, doi: 10.30534/ijatcse/2019/13852019.

[9] S. V. R. Rao, "E- WALLET - A ' PAY , VOLUTION," no. February, 2020.

[10] A. Mulyana and H. Wijaya, "Perancangan E-Payment System pada E-Wallet Menggunakan Kode QR Berbasis Android E-Payment System Design in E-Wallet Using Android-Based on QR Codes," vol. 7, no. 2, pp. 63-69, 2018, doi: 10.34010/komputika.v7i2.1511.

[11] Y. C. Puspita, "Penggunaan Digital Payment Pada Aplikasi Ovo," J. Manaj. Inform., vol. 09, no. 02, pp. 121-128, 2019, [Online]. Available: https://jurnalmahasiswa.unesa.ac.id/index.php/jurnalmanajemen-informatika/article/view/29471/26993.

[12] D. C. Muthurasu and D. M. Suganthi, "an Overview on Digital Library," Glob. J. Res. Anal., no. October 2017, pp. 1-2, 2019, doi: 10.36106/gjra/8906567.

[13] S. R. Das, "The future of fintech," Financ. Manag., vol. 48, no. 4, pp. 981-1007, 2019, doi: 10.1111/fima.12297.

[14] M. A. Chen, Q. Wu, and B. Yang, "How Valuable Is FinTech Innovation?," Rev. Financ. Stud., vol. 32, no. 5, pp. 2062-2106, 2019, doi: 10.1093/rfs/hhy130. 